\title{
CSR initiatives by companies for employees through social protection measures
}

\author{
Noor Akma Mohd Salleh ${ }^{1,}$, Rusnah Muhamad ${ }^{2}$, and Siti Hajar Mohd Roffeei ${ }^{3}$ \\ ${ }^{1}$ Department of Operations and Management of Information Systems, Faculty of Business \& \\ Accounting, 50603 University of Malaya, Malaysia \\ ${ }^{2}$ Department of Accounting, Faculty of Business \& Accounting, 50603 University of Malaya, \\ Malaysia \\ ${ }^{3}$ Institute of Graduate Studies, 50603 University of Malaya, Malaysia
}

\begin{abstract}
Poverty has always been the main concern globally as it alienates and distresses particular groups of citizen that affects their emotion and psychological behaviour, and may have impact on the socioeconomic aspect of the country. Hence, it is critical for the government to address the poverty problem, as this would lead to inequality. One way to minimise income inequality is through the provision of social protection to maintain the basic consumption and living standard of the needed members of the society. The government highlights the importance of increasing involvement of the private sector to improve social protection through their CSR programmes. Thus, the main purpose of this paper is to unearth the concept of social protection and its role in minimising inequality in the society as well as to develop an instrument to measure the social protection dimension of companies' CSR activities.
\end{abstract}

\section{Introduction}

The direct and indirect effects of poverty lead to inequality, as there is disparity of wealth distribution between the rich and poor. It is therefore vital that the necessary actions are effectively implemented to eradicate poverty and subsequently minimise inequality, which in turn will address the issue of equity. Equity means addressing the concern of the society for a fair and equal treatment of opportunities to everybody, regardless of their background. Once we are able to address equity, then equitable society can be achieved.

Utting (2007) considered equity and equality as prerequisites to achieving equitable society. One way of increasing chances towards achieving equitable society is through the Corporate Social Responsibility (CSR) initiatives by companies [1]. The focus of CSR initiatives should then be on improving working conditions, community support, labour and human rights, community empowerment, and stakeholders' participation. It is proposed that the four dimensions of equity and equality are social protection, rights, empowerment, and redistribution [1]. Both the public and private sectors can promote these four dimensions through socially responsible activities.

* Corresponding author: akmasalleh@um.edu.my 
This paper focuses on the social protection dimension of equity and equality. If CSR agenda by companies is to complement the effort of the government in promoting equity and equality via the social protection dimension, there is a need to understand the gap between CSR activities and the welfare of employees and communities. Hence, the aim of this paper is to unearth the concepts of social protection and how companies could contribute in promoting the social protection for the needy as well as to propose the appropriate measure of social protection in relation to CSR initiative by companies. Within the scope of CSR activities by companies, this study notes that the social protection measures discussed in this paper is limited to those related to employees and their family members which may not be inclusive of the other general members of the society.

The remainder of the paper discusses the concept of CSR and social protection followed by a brief description on the research methodology adopted in Section 3. Section 4 examines and determines the definition and measurement for the social protection dimension through CSR activities. The final Section 5 concludes with recommendations for further study.

\section{CSR and social protection}

CSR is a set of policies, practices, and programmes, integrated into business operations, supply chains, and decision-making processes of a company [2]. It also encompasses the economic, legal, ethical, and discretionary (philanthropic) expectations that a society has from business organisations [3]. CSR can be considered as a vehicle for companies to interact with their stakeholders, designed to deliver sustainable value to the society by which activities are based on ethical and philanthropic obligations, and respect for the community, employees, the environment, shareholders, and other related stakeholders [26].

Review of the extent literature revealed that research in CSR were mainly concerned with CSR disclosures $[3,7,8]$, corporate governance and strategic management $[9,10]$, and the emerging political CSR $[2,11]$. Debates on CSR revolved around what theories are most suitable for companies to justify the basis of their CSR activities. It is argued that CSR should firstly be viewed as "corporations' obligations" to work for social betterment $[12,13]$. As such, CSR should move from a philosophical approach to a managerial approach by enabling CSR through "corporate social responsiveness" [12]. Embracing this form of CSR will allow the corporation to react to social forces that introduces the notion of "corporate social rectitude" [13]. This form of CSR considers that in business activities, social and ethical decisions are expected. Therefore, in choosing a social cause for CSR activities, the social cause should be about opportunities for shared value between companies, employees, and the society.

The objective of the social protection on the other hand, is to reduce economic and social vulnerability by providing income or consumption transfers to the poor, protecting the vulnerable against livelihood risks, and enhancing the social status and rights of the marginalised groups [14-15]. At a company level, social protection for employees and their family members often circulates around topics of wages and other fringe benefits. Findings of a study revealed that the most common provisions are different types of benefits including health care benefits and old age pensions [16]. In contrast, it was argued that any expenditure for employees' benefit regarded as compensation for work is not considered a social benefits [17]. These expenditures include cost of living allowances, transport allowances, saving schemes payments for employees, free housing or housing allowances, crèches for the children of employees, holiday package for official holidays, and sports, recreation and holiday facilities for employees and their families [17]. 
Even so, the objective of the International Labour Organization (ILO) is the promotion of decent work, described as opportunities for people to obtain decent and productive work in conditions of freedom, equity, security, and human dignity [18]. The ILO has included the element of social protection in the measurement of decent work, which often provided against life contingencies such as ill health, old age, unemployment, and disability [18]. Another term, social security, also was adopted and nine classes of benefits were established: medical care, sickness benefit, unemployment benefit, old-age benefit, employment injury, family benefit, maternity benefit, invalidity benefit, and survivors' benefit. Mostly employment based, social security systems providers are institutional structures that may be private, public and mixed, compulsory and voluntary, universal and targeted. Despite the institutional diversity, the goal of social security is to provide the basic protection for employees and their families [18]. The objective of social protection in this case is similar with the argument of the social cause which is providing opportunities for shared value between companies and employees [12, 13].

Based on this argument, the "Shared Value" concept was adopted as the underlying theory to understand the CSR initiatives and social protection concept. According to the Shared Value concept, the CSR agenda should be about policies and operating practices that enhance the competitiveness of companies, whilst simultaneously advance the social conditions in the communities which they are operating $[2,19]$. Shared value focuses on integrating social and business advantage that results in new business models which are social and inclusive [20]. With this underlying theory, it is proposed that social protection can be promoted through CSR activities because both social protection and CSR activities focus on providing opportunities for both companies and employees that enhances social status and rights of the marginalised groups in the society.

Primarily, social protection can be promoted through CSR initiatives by focusing on the following components: 1) social insurance, 2) social assistance, and 3) social services. Social insurance provides protection against risks of income loss and shocks [21] whereby it is commonly related to employment and often contributory. The compensatory support of social insurance is provided in the occurrence of illness, injury, disability, death of parent or breadwinner, unemployment (or retrenchment) and old age. Even with its objectives being for protection and promotion, the social insurance system in developing countries tends to cover certain populations that benefit only those employed in the formal sector and their families. As a result, the vast majority of the poor is excluded from the systems [15]. The usually non-contributory social assistance programmes aim at raising the living standards of employees through transfers in cash and in kind [21-23]. Social assistance is a critical mechanism for poverty reduction amongst the developing countries [15]. Social services through CSR initiatives for the vulnerable groups (such as the disabled, women and girls, children and elderly) are designed to provide these groups of people with special care and needs, and access to basic services [21]. Such services may include healthcare, education, and child protection [23].

Companies through its CSR initiatives encourage employees to be involved and engaged in meaningful activities for their companies and the society. The companies in turn, reward employees by paying fair salary and providing other employment benefits. Therefore, a reference on the set of measure related to the above three components of social protection through CSR initiatives need to be explored and examined.

\section{Research methodologies}

A search for literature regarding the three components of social protection through CSR initiatives was initiated by a keyword search around words and phrases such as "social protection", "CSR", "social insurance", "social assistance", and "social services". The 
retrieved articles included academic and non-academic research papers published between the year 2000 and present. The purpose of the literature review was to develop an instrument on the social protection construct based upon the three components (as discussed in Section 2) through CSR initiatives. The published papers were extracted from various databases including relevant studies in psychology, sociology, corporate governance, CSR, and equitable society within the context of the Shared Value concept. Thirty-five (35) papers pertaining to the definitions and concept of social protection were mostly concentrated in the non-academic publications. Content analysis method was used in developing the instrument which consisted of three steps. Step one required identification, review, and screening of the definition and concept of social protection components. When such refined definitions were finalised, step two involved assessment of the pertinent constructs of social protection. Finally, step three established the measurement items for social protection construct (through companies' CSR initiatives focusing on employees).

\section{Social protections: Definition, concept and measurement}

\subsection{Definition of social protection}

There were many descriptions on concept and definition of social protection in the academic and non-academic literature. One of the papers reviewed defines social protection based on the World Bank definition; Social protection is a collection of measures or interventions to improve or protect human capital (i.e., individuals, households, communities), ranging from labour market interventions and publicly mandated unemployment or old-age insurance, to targeted income support [14]. In another paper it was stated that social protection enables vulnerable groups (i.e., the poor as well as nonpoor) to prevent, reduce, and/or cope with risks [24]. The United Nations defined social protection as a set of public and private policies and programmes in response to various contingencies due to absence or substantial reduction of income from work, to assist families with children, and provide basic healthcare and housing [25]. In a similar way, the ILO described the various contingencies as sickness, maternity, employment injury, unemployment, invalidity, old age, and death of breadwinner [25]. A working definition for social protection is a set of actions undertaken through the provision of social insurance, social assistance, and social inclusion efforts $[15,26]$. Other recognised forms or mechanisms of social protection include social transfers, social services, and social transformation [27].

Surprisingly, there was limited academic literature that discussed social protection in terms of definition and concept. Social protection was broadly defined as the welfare and wellbeing of workers and other groups of people or stakeholders [1]. Social protection is also described as public measures that provide income security for individuals [28]. Social safety nets is defined as the informal or less formal systems of social protection and the formal social security or social insurance system [29].

The key trend observed from all these definitions focused on the objectives and the instruments used to understand the concept and measurement of social protection. The objective is generally to tackle poverty, risks, and vulnerability. Noting how social protection definition was based on its objectives, this paper thus defines social protection as the set of measures being provided for the welfare and wellbeing of employees and other groups of people or stakeholders which aims at protecting these groups against economic and social distress of various contingencies that would be caused by the absence or a substantial reduction of income from work as described by ILO [25]. Social protection also 
includes the provision of healthcare and benefits for families with children. Hence, the ultimate goal of social protection is in achieving equity and equality by minimising deprivation and enhancing income and labour opportunities to all.

\subsection{The concept of social protection}

Social protection measures can have different and often overlapping objectives and impacts. For example, social protection objectives can be about promoting incomes and at the same time preventing deprivation. The review of the extant literature revealed that there are three main measures of social protection: protective measures, preventive measures, and promotional measures $[14,15]$.

Protective measures are meant to relief deprivation by which the initiatives are usually designed for the poor and can be in the form of cash and in-kind. Such measures may include disability benefits, non-contributory pensions, fee waivers, work schemes, supplementary diets, and food aid (forms of safety net), especially needed in smoothing consumption during crisis [18].

Preventive measures avert deprivation through social insurance (such as pensions and maternity benefits), and social services (such as family counselling, juvenile justice services, and protection and prevention against family violence). The social insurance initiatives aimed at protecting people against risks of shocks whilst social services targeted the marginalised groups $[14,15]$.

The third measure of social protection is known as the promotive measures. It is designed to enhance real incomes and capabilities of employees, social assistance as springboard aimed at providing employment opportunities to reduce poverty. The provision of social assistance may be in the form of cash and in-kind transfers [14, 15].

\subsection{Measurement of social protection}

Companies of all sizes share an important role in the society. Despite the focus on economic and investment returns, these companies have roles to play in relation to social, human, technological, and environmental development [30]. Therefore, these four aspects of development were included in the establishment of the measurement of social protection via CSR initiatives. An ILO document was the main resource for developing the measurement [31]. The chosen items were adopted with respect to the concept of social protection as discussed in the Section 4.2. Nine items were identified as the appropriate measures of social protection via CSR initiative, categorised into three main components (i.e. social insurance, social assistance, and social services) as described in Section 2. Table 1 shows the components and items of measurement.

Table 1. Components and items for measuring social protection by CSR initiatives

\begin{tabular}{|l|l|}
\hline Component & Item \\
\hline SI & $\begin{array}{l}\text { Companies should establish a pension plan to sustain employees' lives after } \\
\text { retirement }\end{array}$ \\
\hline SI & $\begin{array}{l}\text { Companies should establish a retrenchment plan (e.g. involuntary separation, } \\
\text { voluntary separation-VSS, mutual separation-MSS) to appropriately compensate } \\
\text { retrenched employees }\end{array}$ \\
\hline SI & $\begin{array}{l}\text { Companies should contribute to employment injury insurance to provide for } \\
\text { employees' injuries and disabilities caused by work-related accidents }\end{array}$ \\
\hline SI & $\begin{array}{l}\text { Companies should provide paid leaves for employees (e.g. sick leave, maternity } \\
\text { leave, compassionate leave, etc.) to ensure a work-life balance and improve } \\
\text { productivity levels at work }\end{array}$ \\
\hline
\end{tabular}




\begin{tabular}{|c|c|}
\hline SI & $\begin{array}{l}\text { Companies should contribute to employment insurance scheme which provides } \\
\text { financial supports (e.g. funeral expenses, scholarship, pension) for employees' } \\
\text { next of kin in the event of death and permanent disabilities of employees }\end{array}$ \\
\hline SA & $\begin{array}{l}\text { Companies should provide facilities (e.g. accessible toilets, ramp, parking bays, } \\
\text { emergency lights, signage, resting place, transport to work) for disabled } \\
\text { employees/customers at companies' premises }\end{array}$ \\
\hline SA & $\begin{array}{l}\text { Companies should contribute to invalidity pension scheme to provide for } \\
\text { employees' disabilities arising from chronic diseases (e.g. heart attack, kidney } \\
\text { failure, cancer, mental illness, chronic asthma, etc.) }\end{array}$ \\
\hline SS & $\begin{array}{l}\text { Companies should provide childcare services (e.g. community childcare, } \\
\text { kindergarten) }\end{array}$ \\
\hline SS & $\begin{array}{l}\text { Companies should provide healthcare scheme for employees (e.g. generalist } \\
\text { outpatient, dental/optical subsidy, maternity benefits, hospitalisation benefits) }\end{array}$ \\
\hline
\end{tabular}

\section{Summary and conclusions}

The concept and measurement of social protection through CSR initiatives by companies discussed in this paper can be considered as a contribution to the body of knowledge. The paper defines social protection focusing on the welfare and wellbeing of employees, their family members, and other related stakeholders. Social protection can be categorised into three main components, namely, social insurance, social assistance, and social services. These components are measured based on the protective, preventive, and promotive objectives of social protection. Based on the review of the extant literature, we have proposed nine items to appropriately measure the contribution of companies in improving the social protection dimension among employees through their CSR initiatives. It is recommended that in future, an empirical research be conducted adopting the propose instrument to assess the roles and impact of social protection on equity and equality.

\section{Acknowledgments}

We would like acknowledge the financial support provided by University of Malaya under the Equitable Society Research Cluster ((ESRC) research grant RP030B-15SBS.

\section{References}

1. P. Utting, Third World Q. 28, 697-712 (2007)

2. S. R. Abdulrazak, S. F. Ahmad, Int. J. Global Bus. Manag. Res. 6, 210-218 (2014)

3. A. B. Carroll, K. M. Shabana, Int. J. Manag. Rev. 85-105 (2010)

4. F. Z. Abdul Hamid, R. Atan, Int. J. Bus. Soc. Sc. 2, 198-208 (2011)

5. A. Bidin, Mal. J. Law Soc. 12, 175-189 (2008)

6. M. Ismail, J. Int. Soc. Res. 2/9, 119-209 (2009)

7. M. A. Omran, D. Ramdhony, Int. J. Acc. Finan. Report 5, 38-55 (2015)

8. S. van der Laan, Australas. Acc. Bus. Finan. J. 3, 2 (2009)

9. S. Brammer, G. Jackson, D. Matten, Soc. Econ. Rev. 10, 3-28 (2012)

10. D. Crowther, G. Aras, Corporate Social Responsibility (2008)

11. J. G. Frynas, S. Stephens, Int. J. Manag. Rev. 17, 483-509 (2015)

12. W. C. Frederick, Bus. \& Soc. 33, 150 (1994)

13. W. C. Frederick, California Manag. Rev. 28, 126-141 (1986)

14. S. Deveraux, R. Sabates-Wheeler, Transformative Social Protection (2004) 
15. P. White, A. Hodges, M. Greenslade, Measuring and Maximising Value for Money in Social Protection Systems (2015)

16. International Labour Organization, Legal basis and reporting tools (2006) Retrieved from http://www.social-protection.org/gimi/gess/ShowTheme.action?id=3446

17. European Union, ESSPROS Manual and User Guidelines (2012)

18. International Labour Office (ILO), Measuring Decent Work with Statistical Indicators (2002)

19. K. Dembek, P. Singh, V. Bhakoo, J. Bus. Ethics (2016)

20. L. Michelini, D. Fiorentino, Soc. Responsibility J. (2012)

21. S. Abdul Samad, N. Mansor, Malaysian J. Econ. St. 50, 139-156 (2013)

22. S. Cecchini, J. Southeast Asian Econ. 31, 18-39 (2014)

23. S. Cook, J. Pincus, J. Southeast Asian Econ. 31, 1-17 (2014)

24. S. W. Handayani, ADB Sustainable Development Working Paper Series 32 (2014)

25. R. Yemtsov, The World Bank and Social Protection Overview (2013)

26. P. Brunori, M. O'Reilly, Social Protection for Development: A Review of Definitions (2010)

27. Institute of Development Studies (IDS), Adaptive Social Protection (2012)

28. R. Holzmann, S. Jorgensen, Int. Tax Public Finan. 8, 529-556 (2001)

29. R. Mat Zin, ASEAN Econ. Bul. 29, 197-217 (2012)

30. J. Aston, C. Anca, Socially Responsible Small and Medium Enterprises (SMEs): Guide on Integrating Social Responsibility into Core Business (2011)

31. International Labour Office (ILO), Toolkit for Mainstreaming Employment and Decent Work (2007) 